\title{
Active cell balancing for electric vehicle battery management system
}

Thiruvonasundari Duraisamy, Deepa kaliyaperumal

Department of Electrical and Electronics Engineering, Amrita School of Engineering, India

\begin{tabular}{l}
\hline Article Info \\
\hline Article history: \\
Received Sep 5, 2019 \\
Revised Nov 11, 2019 \\
Accepted Feb 4, 2020 \\
\hline
\end{tabular}

Keywords:

Battery management system Cell balancing

Electric vehicle

Lithium ion battery

State of charge

\begin{abstract}
The shrink in accessibility of petroleum products and increment in asset request are eventual outcomes for Electrical Vehicles (EVs). The battery has an impact on the performance of electrical vehicles, the driving range. Lithium ion (Li-ion) chemistry is extremely sensitive to overcharge and deep discharge, which can harm the battery, shortening its period of time, and even inflicting risky things. The Battery Management System (BMS) comprises of the consequent parts: management, equalization and protection. Of the three components, equalization is that the most crucial with respect to the durability of the battery framework. The ability of the full pack diminishes rapidly amid the procedure which leads to degradation of the full battery framework. This condition is extreme once the battery incorporates a more number of cells in series and frequent charging is conveyed through the battery string. The cell imbalance during charging, discharging is a major issue in battery systems used in EVs. To circumvent the cell imbalance, cell balancing is used. Cell balancing enhances battery safety and extends battery life. This paper discusses about different active balancing method to increase the life span of the battery module. Based on the comparison, the inductor based balancing method for $60 \mathrm{~V}$ battery system is implemented in the MATLAB/Simscape environment and the results are discussed.
\end{abstract}

This is an open access article under the CC BY-SA license.

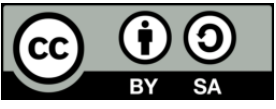

\section{Corresponding Author:}

Thiruvonasundari Duraisamy,

Department of Electrical and Electronics Engineering,

Amrita Vishwa Vidyapeetham University, Amrita School of Engineering,

Bangalore, Karnataka, India.

Email: sundarisamy@gmail.com

\section{INTRODUCTION}

Battery frameworks having Li-ion cells are inclined to fast cell deterioration and burst into flames or cause to detonate. Intelligent circuits and programming advancements are set up to moderate these impending threats. In a multi cell battery pack, which is normally utilized in EVs restorative hardware, setting cells in arrangement leads to the likelihood of the cell imbalance, a slow, however, constant degradation of the battery. Cells are of indistinguishable nature. There is constantly slight change in the condition of the State of Charge (SoC), capacity, self discharge, temperature and internal impedance qualities, notwithstanding for cells that are a similar model from a similar maker and even from a similar cluster of creation [1]. When building multi cell packs, makers typically separate cells with comparative SoC based on the voltage. Voltage dissimilarities between the cells arise after some time due to significant change in the battery variables. By checking the voltage-guideline point of the battery pack the charger recognizes the fully-charged state. Due to internal parameter variations, any cell in the battery pack may reach 
the overvoltage limit compares to other cells in the string. The condition of the overcharged cell worsens further by repeated charge and discharge cycles and its leads to capacity deterioration.

To give a dynamic solution for this issue while considering the age along with the working states of the batteries, the BMS would attempt to integrate one of the two cell equalization techniques to balance the cells and to prevent them from getting overemphasized [2]: the passive and active cell equalization. The high voltage cell is identified and the excess energy is dissipated across the resistor until its voltage matches with the weak cells in the passive scheme [3]. In the active topology the over charged cell energy is evacuated and given to the undercharged cells by using energy transferring elements [4]. The Figure 1 shows the different cell balancing topologies which is available for the battery powered system.

This paper discusses about the various active balancing topologies along with its equalization speed, application, size, cost, design and efficiency. Section 2 explains the various cell balancing topologies and the balancing techniques are compared. Section 3 represents the inductor-based topology implemented for $60 \mathrm{~V} \mathrm{Li}$ - ion battery system in MATLAB/Simscape and the simulation results are discussed followed by the conclusion.

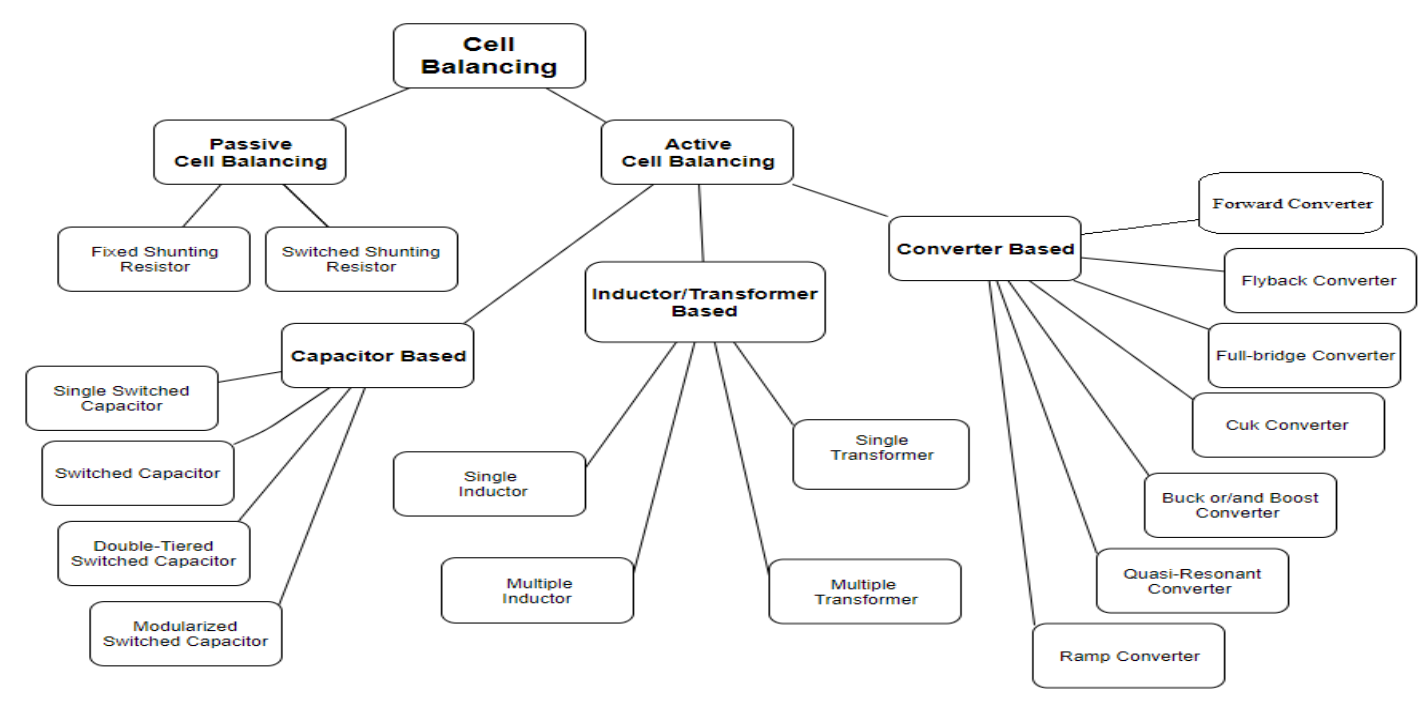

Figure 1. Balancing topologies

\section{BALANCING TOPOLOGIES}

\subsection{Active cell balancing method}

In this balancing scheme, the excess energy is shifted from the overcharged cell to the weaker cell in the pack. Unlike passive balancing scheme, here energy is not wasted as heat instead it is transferred to other cells.

\subsubsection{Capacitor based topologies}

In a capacitor-based topology as represented in Figure 2, the capacitors are used for exchanging unequal charge among numerous cells in the battery pack. Single Switched Capacitor utilizes a single capacitor, makes the system more cost-productive than double tiered switched capacitor and switched capacitor [5].

Switched Capacitor transfers energy between adjacent cells. In order to reduce the balancing time a chain structured switched capacitor topology was introduced [6] and series-parallel switched capacitor and equalizer for various speed requirement [7]. A couple of changes made to switched capacitor strategy results in Double-Tiered Switched Capacitor (DTSC). The uniqueness in this is, 2 capacitors are used for energy shuttling purposes. For more series connected cells the balancing speed of DTSC is slower and it is overcome in [8] by using resonant topologies.

Modularized switched capacitor is a different type of capacitive storage device topology which also includes shuttling capacitor techniques [9-11]. It includes battery pack modularization, splitting the battery string into modules or groups. To reduce the switching losses, conduction losses and to improve the balancing speed resonant switched capacitor, based on that the balancing is used $[12,13]$.

Int J Pow Elec \& Dri Syst, Vol. 11, No. 2, June 2020 : $571-579$ 


\subsubsection{Inductors/transformers-based topology}

Inductor/transformer based active equalizer as represented in Figure 3 transfers energy among multiple cells with the help of magnetic components such as inductors and transformers. Single Inductor Cell Balancing is based on the buck boost techniques where energy transfer takes place from highly charged battery to low charged battery and to achieve this voltage, monitoring circuits are required for every battery [14]. Multiple inductor cell balancing topology using more than one inductor to balance the multiple cells simultaneously. Cell balancing based on optimized cell to cell, any cell to any cell and parallel inductor architecture is discussed in [15-18].

In the single transformer cell topologies only one transformer is used to share the charge between the batteries with fast equalization speed and low magnetic losses [19, 20]. It transfers energy from a pack to the undercharged cell called as pack to cell method and overcharged cell to the entire pack called as cell to pack method. Multiple transformer topologies can balance more than one cell at the time of imbalance.

\subsubsection{Converter based topology}

This dynamic cell equalization circuit as represented in Figure 4 balances the imbalanced cells in the pack through a DC-DC converter [21, 22], for example, buck-boost or forward converter. Converter based topologies are very efficient and have a good control over the power flow [23-25]. In a forward converter, in presence of voltage difference, the cell which is having high energy is transferred to the other weak cells through transformer windings, diodes and switches [26]. In the Fly back converter-based cell balancer, when the auxiliary side switch is turned on, the energy gets delivered to cells with low voltage from high voltage cells through the diode since the estimation of high voltage on any cells gets put away in the transformer [27].

Full-bridge Converter is also called as fully controlled converter. Boost and buck mode are two modes of operation of full-bridge converter [28]. The cuk converter is like buck-boost cell balancer. It can increment or decrease the output voltage. It can be applicable for balancing only the neighbouring cells $[29,30]$. The buck boost topology is used where the voltage deviations among the cells are minimum and the applications need high balancing currents [31].

Quasi-Resonant converter is a highly efficient converter because the switches are on \& off at zero voltage and/or zero current. In this equalizer inductors \& capacitors are made as the resonant tank to attain the ZCS function [32]. Ramp Converter is additionally an enhancement for the multiple winding transformer equalization circuit. This topology just needs one additional (optional) twisting for the pair of cells rather than one for every cell [33].

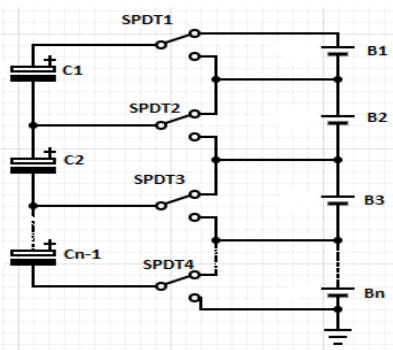

Figure 2. Capacitor Based

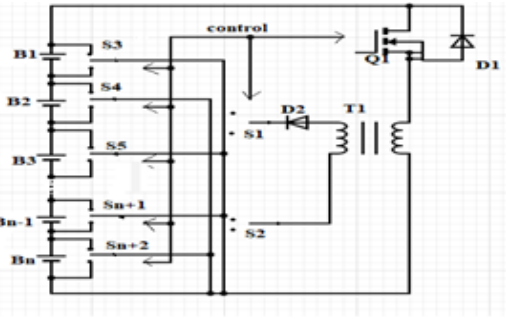

Figure 3. Inductor/ Tranasformer Based

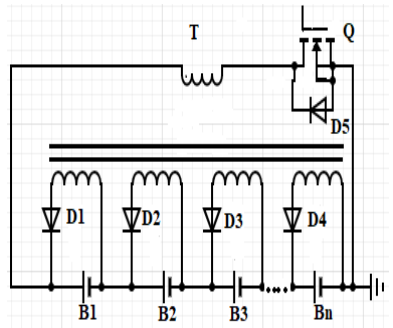

Figure 4. Converter Based

\subsection{Comparison of active balancing topologies}

The Table. 1 compares the various cell balancing topologies based on the balancing speed, reliability, control strategy, efficiency, etc.

The control system and plan perspectives are the two significant criterias for the choice of active cell balancing topologies. Control qualities are identified with dependability and methods of activity, which comprises of charge and discharge control [34, 35]. Basic control implies better dependability. In light of the correlation the inductor-based topology is the better topology for charging as well as discharge balancing. 
Table 1. Comparison of active cell balancing topologies

\begin{tabular}{|c|c|c|c|c|c|c|c|c|}
\hline Type & $\begin{array}{l}\text { Balancing } \\
\text { speed }\end{array}$ & Reliability & $\begin{array}{l}\text { Control } \\
\text { strategy }\end{array}$ & Cost & Size & $\begin{array}{l}\text { Charge \& } \\
\text { Discharge }\end{array}$ & Efficiency & Application \\
\hline $\begin{array}{l}\text { Single } \\
\text { capacitor }\end{array}$ & Low & Medium & Hard & High & Bulk & Both & High & $++/+++$ \\
\hline $\begin{array}{l}\text { Multiple } \\
\text { Capacitors }\end{array}$ & Very low & Medium & Moderate & Medium & Moderate & Both & High & $++/+++$ \\
\hline $\begin{array}{l}\text { Single/Multiple } \\
\text { Inductors }\end{array}$ & Medium & Medium & Hard & Medium & Moderate & Both & Medium & $++/+++$ \\
\hline Single Transformer & Low & Low & Hard & Low & Moderate & $\begin{array}{l}\text { Charge } \\
\text { alone }\end{array}$ & Low & ++ \\
\hline $\begin{array}{l}\text { Multiple } \\
\text { Transformer }\end{array}$ & Low & Low & Moderate & Low & Compact & $\begin{array}{l}\text { Charge } \\
\text { alone }\end{array}$ & Low & ++ \\
\hline Forward Converter & Medium & Medium & Hard & Medium & Moderate & Both & Medium & ++ \\
\hline Fly back converter & Low & Low & Moderate & Medium & Moderate & Both & Medium & ++ \\
\hline Full bridge converter & High & Medium & Hard & Low & Compact & Both & High & ++ \\
\hline Cuk converter & Medium & Medium & Hard & Medium & Moderate & Both & Medium & $++/+++$ \\
\hline $\begin{array}{ll}\text { Buck } & \text { or/boost } \\
\text { converter }\end{array}$ & High & High & Hard & Medium & Moderate & Both & High & $++/+++$ \\
\hline $\begin{array}{l}\text { Quasi-resonant } \\
\text { converter }\end{array}$ & Low & Very low & Hard & Low & Moderate & Both & Medium & $++/+++$ \\
\hline Ramp converter & Low & Very low & Hard & Low & Moderate & Both & Low & ++ \\
\hline
\end{tabular}

+ - Low power, ++ - Medium power, +++ - High power

\section{Inductor based active cell balancing}

The inductor based active cell balancing topology is actualized for $60 \mathrm{~V} \mathrm{Li-ion} \mathrm{battery} \mathrm{framework}$ which comprises of 16 cells associated in an arrangement. Regular inductor-based topology sets aside a great deal of effort to exchange the charge from the principal cell to the last cell in the string. So, the effectiveness of the traditional topology isn't satisfactory. In the proposed cell balancing topology a smaller number of switches and inductors are utilized $[17,18]$ contrasted with conventional inductor-based techniques which lessen

the power misfortunes and improve the proficiency. The square chart of 16 cell inductor-based cell adjusting topology is appeared in Figure 5 which comprises of ' $n$ ' lithium ion cells and (n-1) inductors and (2n-2) switches so absolutely for 16 cells 15 inductors and 30 switches are utilized.

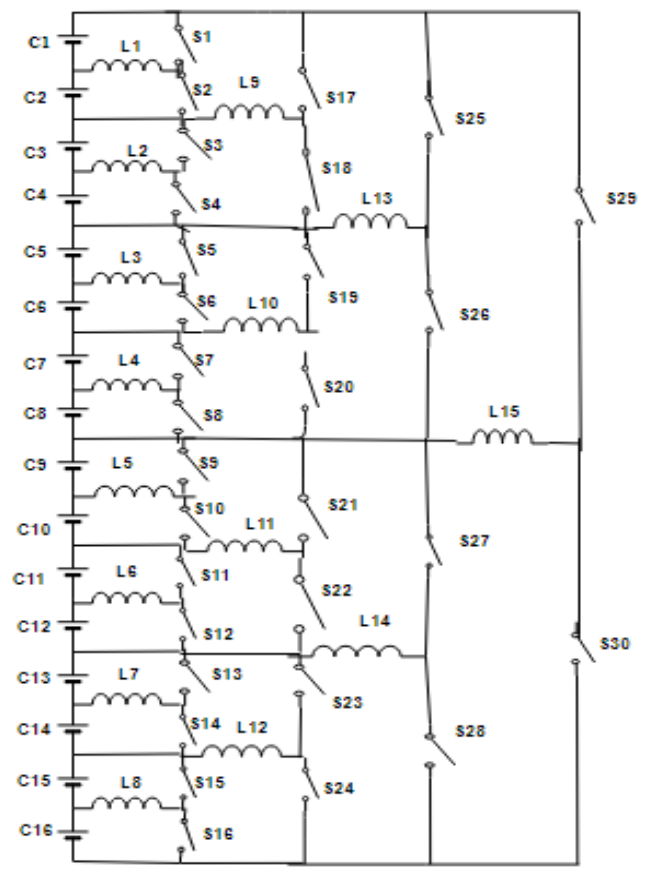

Figure 5. Proposed inductor-based topology 


\subsection{Control methodology}

The control methodology executed in this topology is based on the voltage deviation among the cells. Right off the bat, all the cell voltages are estimated. The process of acquiring abnormal battery cells and the application of active cell balancing is described in Figure 6.

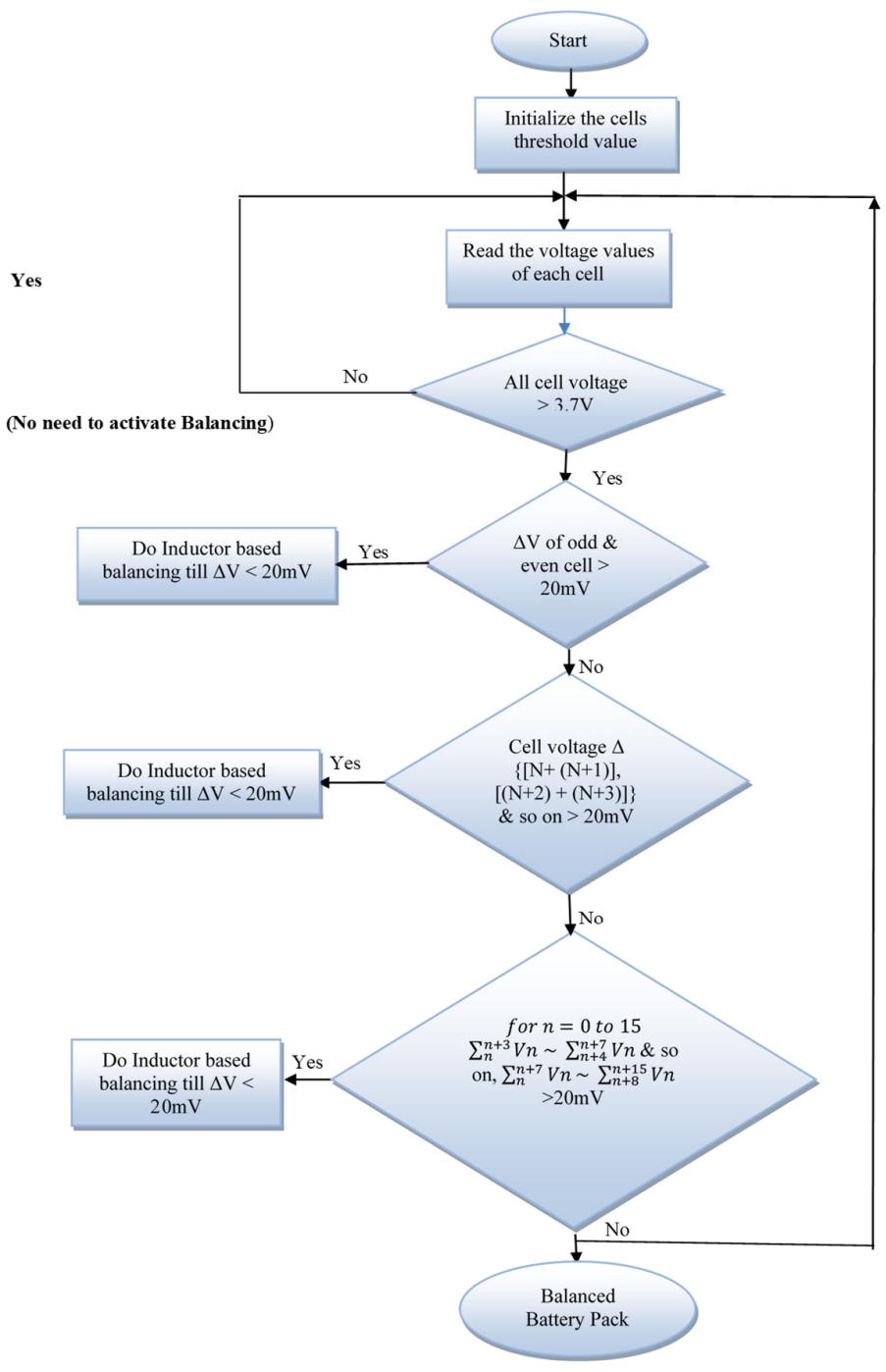

Figure 6. Active balancing control flowchart

\subsubsection{First stage}

The voltage distinction between the odd numbered cells $(\mathrm{C} 1, \mathrm{C} 3 \ldots \mathrm{C} 15)$ with its contiguous even numbered cell $(\mathrm{C} 2, \mathrm{C} 4 \ldots \mathrm{C} 16)$ is more than the threshold voltage $(20 \mathrm{mV})$, at that point the overcharged cell is switched on \& the inductor is charged. When the voltage distinction is underneath normal then the switch is turned off, the stored energy in the inductor is given to the low charged cell through the body diode of the switch. The voltage across the inductor L1,

$$
\begin{aligned}
& V_{L 1}=L_{1}\left(\frac{d i_{L 1}}{d t}\right)=V_{c e l l 1} \\
& V_{L k}=L_{k}\left(\frac{d i_{L k}}{d t}\right)=V_{c e l l j}
\end{aligned}
$$


Where, $\mathrm{k}=2,3 \ldots . .8$, and $\mathrm{j}=3,5 \ldots \ldots 15$

For instance, if the voltage contrast between odd numbered cells is more than $20 \mathrm{mV}$ contrast with even numbered cells, odd numbered switches S1...S15 are on and the energy is stored in the inductor. When it is below the threshold, the switches are turned off, the inductor energy is given to the even cells.

\subsubsection{Second stage}

In the second stage, the initial two cell voltage $\left(V_{1}+V_{2}\right)$ is contrasted with the next two cell voltage $\left(\mathrm{V}_{3}+\mathrm{V}_{4}\right)$ in the event that it is more than $20 \mathrm{mV}$, at that point the profoundly charged cell switch is turned on. The strategy is same for the remaining cells.

$$
\begin{aligned}
& V_{L 9}=L_{1}\left(\frac{d i_{L 9}}{d t}\right)=V_{c e l l 1}+V_{c e l l 2} \\
& V_{L k}=L_{k}\left(\frac{d i_{L k}}{d t}\right)=V_{c e l l j}+V_{c e l l i}
\end{aligned}
$$

Where, $\mathrm{k}=10,11,12, \mathrm{j}=5,7,9 \ldots 15$ and $\mathrm{i}=6,8,10 \ldots .16$

\subsubsection{Third stage}

In this stage, the cell voltages $\left(\mathrm{V}_{1}+\mathrm{V}_{2}+\mathrm{V}_{3}+\mathrm{V}_{4}\right)$ are contrasted with $\left(\mathrm{V}_{5}+\mathrm{V}_{6}+\mathrm{V}_{7}+\mathrm{V}_{8}\right)$ and the cell voltages $\left(V_{9}+V_{10}+V_{11}+V_{12}\right)$ are contrasted with $\left(V_{13}+V_{14}+V_{15}+V_{16}\right)$. In light of the voltage deviation the corresponding switches are turned on.

$$
\begin{aligned}
& V_{L 13}=L_{13}\left(\frac{d i_{L 13}}{d t}\right)=V_{c e l l 1}+V_{c e l l 2}+V_{c e l l 3}+V_{c e l l 4} \\
& V_{L 14}=L_{14}\left(\frac{d i_{L 14}}{d t}\right)=V_{c e l l 9}+V_{\text {cell } 10}+V_{\text {cell } 11}+V_{\text {cell } 12}
\end{aligned}
$$

\subsubsection{Fourth stage}

In this stage the top 8 cell voltages are contrasted with the bottom 8 cell voltages. The comparing cell switches are turned on dependent on the voltage contrast.

$$
V_{L 15}=L_{15}\left(\frac{d i_{L 15}}{d t}\right)=V_{c e l l 1}+V_{c e l l 2}+V_{c e l l 3}+V_{c e l l 4}+V_{\text {cell } 5}+V_{\text {cell6 }}+V_{\text {cell } 7}+V_{\text {cell8 }}(7)
$$

This proposed inductor-based topologies can even out top, centre and base cells at the same time with more prominent equalization speed contrasted with the regular technique.

\subsection{Simulation results}

So as to check the usefulness of the framework, the proposed model is simulated under charging condition in the MATLAB/Simscape environment. The battery model parameter values are taken from the lookup table. The voltage difference between the cells is made by changing the initial condition of charge (SoC) of the pack. The lithium ion cells are charged at CC-CV mode. The 16 cells are associated in arrangement so as to get the $60 \mathrm{~V}$. The capacity of each cell is $3.3 \mathrm{Ah}$. The inductor value selected for this topology is $60 \mathrm{mH}$. For every cell, the terminal voltage, open circuit voltage, temperature and SoC are determined. In light of the terminal voltage of the cells the equalization technique is executed.

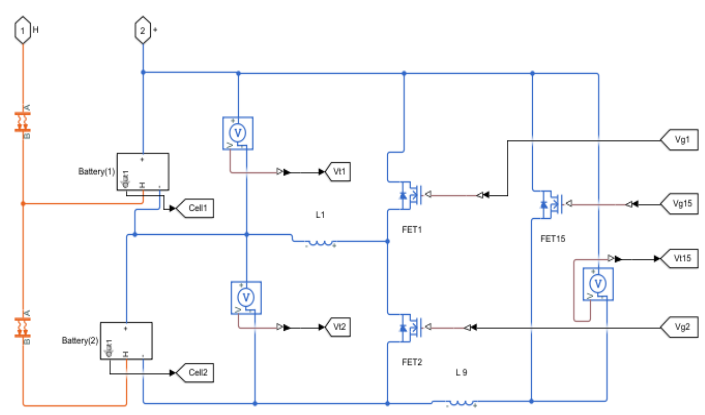

Figure 7. Cell $1 \&$ Cell 2 subsystem in Matlab

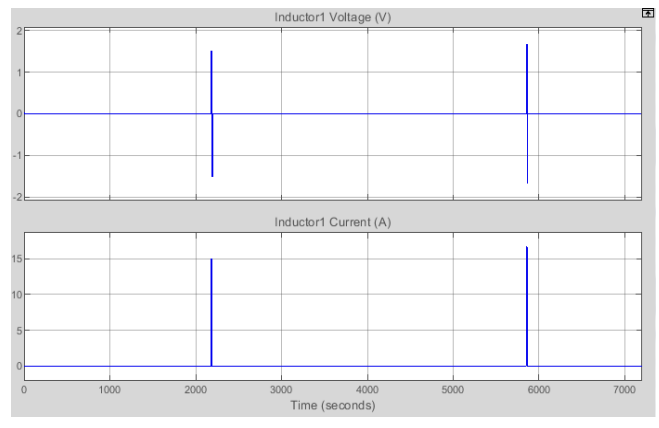

Figure 8. Inductor 1 voltage \& current waveforms

Int J Pow Elec \& Dri Syst, Vol. 11, No. 2, June 2020 : 571 - 579 
Initially the voltage difference between the cell 1 and the cell 2 is $25 \mathrm{mV}$. The cells are charged at consistent current and steady voltage mode. The cells are charged at $0.5 \mathrm{C}$ rate. When the cells are come to threshold charge voltage (3.7), the cell balancing technique is executed. Figure 7 represents the subsystem for cell 1 and cell 2 in MATLAB/Simscape.

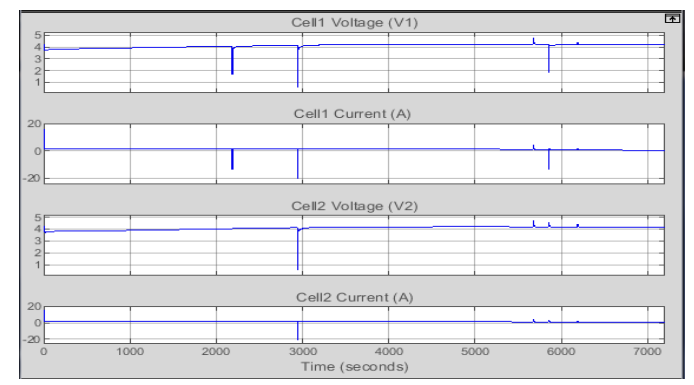

Figure 9. Voltage \& current waveforms of cell $1 \& 2$

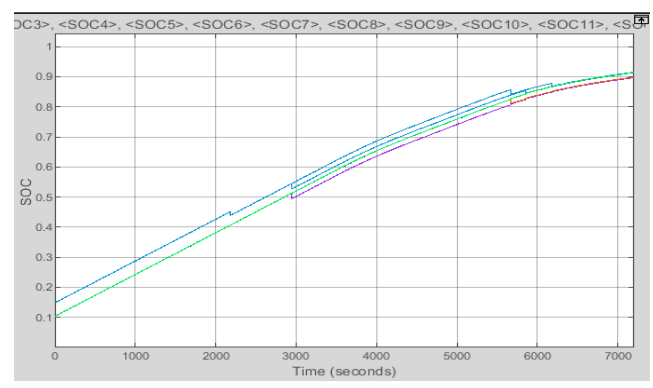

Figure 10. Battery cell SoC

Figure 8 Shows the voltage and current waveforms of the inductor 1 during balancing. The cell 1 voltage is higher than the cell 2 voltage, switch S1 is turned on. The inductor1 is charged through S1.Once the voltage difference between the two cells are less than $20 \mathrm{mV}$, switch S1 turned off. At 5800s the energy stored in the inductor 1 is given to cell 2 through the body diode of the switch S2. Since the threshold voltage limits between the cells are less, the cell voltage variations are not very high as shown in Figure 9.

This balancing topology took 50 minutes to balance the cell voltage equally and it took around 2 hours for complete charging. Since the whole cell voltages are balanced to the same level, the SoC of the cells are the same at the end of charge which is appeared in Figure 10. The charging procedure happens in an ambient temperature of around $20^{\circ} \mathrm{C}$. Amid charging the temperatures of the cells are increasing up to $24.75^{\circ} \mathrm{C}$ appeared in Figure 11.

In the second stage cell $1 \&$ cell 2 voltages are compared with cell $3 \&$ cell 4 voltages. Third stage cell 1, 2, $3 \& 4$ voltages are compared with cell 5, 6, $7 \& 8$ voltages. Forth stage cell 1, 2, 3, 4, 5, 6, $7 \& 8$ voltages are compared with cell $9,10,11,12,13,14,15 \& 16$ voltages.

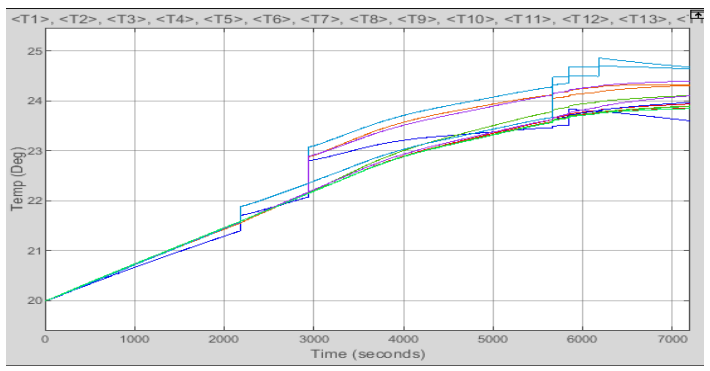

Figure 11. Battery cell temperature

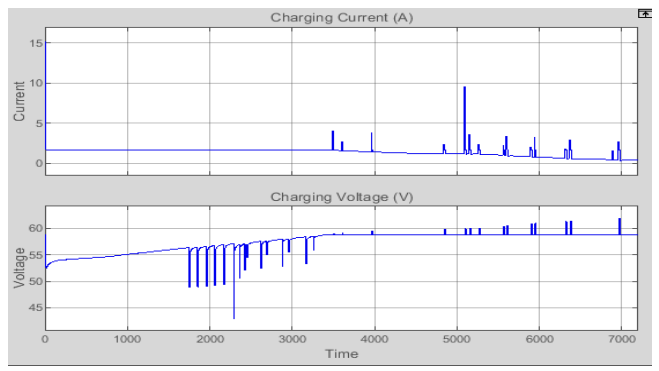

Figure 12. Charging current and voltage

Amid charging, the cells are charged at steady current however the voltage is differing. When the cell achieves the most extreme limit voltage then it moves to the steady voltage mode where it keeps up the voltage as a constant and the current will achieve the base value. This relationship is appeared in Figure 12 .

\section{CONCLUSION}

Diverse active cell balancing topologies are discussed in this paper. Inductor based topology is picked up for utilization based on the assessment and analysis. The proposed topology can alter top, middle and base cells simultaneously with a smaller number of parts than standard inductor-based systems. The control strategies implemented on the switches are based on the voltage difference between the cells. Simple 
control and fast equalization are the advantages of this topology compared to the conventional inductor-based topology. The 16-cell inductor-based equalization topology is simulated in MATLAB/Simscape and the ideal cell equalization is established and checked from the re-enactment yield.

\section{ACKNOWLEDGEMENT}

This work has been supported by Robert Bosch Engineering and Business Solution Limited, Bangalore, India.

\section{REFERENCES}

[1] M. A. Hannan, et al., "State-of-the-Art and Energy Management System of Lithium-Ion Batteries in Electric Vehicle Applications: Issues and Recommendations," in IEEE Access, vol. 6, pp. 19362-19378, 2018.

[2] Z. B. Omariba, et al., "Review of Battery Cell Balancing Methodologies for Optimizing Battery Pack Performance in Electric Vehicles," in IEEE Access, vol. 7, pp. 129335-129352, 2019.

[3] Amin, et al., "Passive balancing battery management system using MOSFET internal resistance as balancing resistor," 2017 International Conference on Sustainable Energy Engineering and Application (ICSEEA), Jakarta, pp. 151-155, 2017.

[4] M. Caspar, et al., "Systematic Comparison of Active Balancing: A Model-Based Quantitative Analysis," in IEEE Transactions on Vehicular Technology, vol. 67, no. 2, pp. 920-934, Feb. 2018.

[5] Mohamed Daowd, et al., "Single Switched Capacitor Battery Balancing System Enhancements," Energies, vol. 6, pp. 2149-217, 2013.

[6] M. Kim, et al., "A Chain Structure of Switched Capacitor for Improved Cell Balancing Speed of Lithium-Ion Batteries," in IEEE Transactions on Industrial Electronics, vol. 61, no. 8, pp. 3989-3999, Aug 2014.

[7] Y. Ye and K. W. E. Cheng, "Modelling and Analysis of Series-Parallel Switched-Capacitor Voltage Equalizer for Battery/Super capacitor Strings," in IEEE Journal of Emerging and Selected Topics in Power Electronics, vol. 3, no. 4, pp. 977-983, Dec 2015.

[8] Y. Ye, et al., "Topology, Modelling, and Design of Switched-Capacitor-Based Cell Balancing Systems and Their Balancing Exploration," in IEEE Transactions on Power Electronics, vol. 32, no. 6, pp. 4444-4454, Jun 2017.

[9] Y. Shang, N. Cui, B. Duan and C. Zhang, "Analysis and Optimization of Star-Structured Switched-Capacitor Equalizers for Series-Connected Battery Strings," in IEEE Transactions on Power Electronics, vol. 33, no. 11, pp. 9631-9646, Nov. 2018.

[10] Y. Shang, et al., "A Delta-Structured Switched-Capacitor Equalizer for Series-Connected Battery Strings," in IEEE Transactions on Power Electronics, vol. 34, no. 1, pp. 452-461, Jan. 2019.

[11] Y. Shang, et al., "An Optimized Mesh-Structured Switched-Capacitor Equalizer for Lithium-Ion Battery Strings," in IEEE Transactions on Transportation Electrification, vol. 5, no. 1, pp. 252-261, March 2019.

[12] S. Goodarzi, et al., "Design and implementing of a novel resonant switched-capacitor converter for improving balancing speed of lithium-ion battery cells," 2016 7th Power Electronics and Drive Systems Technologies Conference (PEDSTC), Tehran, pp. 204-210, 2016.

[13] Farzan Moghaddam, A and Van den Bossche, A. "A cell equalization method based on resonant switched capacitor balancing for Lithium ion batteries," Presented at the 2018 9th International Conference on Mechanical and Aerospace Engineering (ICMAE), IEEE, pp. 337-341, 2018.

[14] Rigvendra Kumar Vardhan, et al., "Modeling of single inductor based battery balancing circuit for hybrid electric vehicles," IECON -43rd Annual Conference of the IEEE Industrial Electronics Society, pp. 2293-2298, 2017.

[15] B. Dong, et al., "Parallel Architecture for Battery Charge Equalization," IEEE Transactions on Power Electronics, vol. 30, no. 9, pp. 4906-4913, Sept 2015.

[16] Zhou, et al., "An any-cell(s)-to-any-cell(s) equalizer based on bidirectional inductor converters for series connected battery string," 2016 IEEE 11th Conference on Industrial Electronics and Applications (ICIEA), Hefei, pp. 2511-2515, 2016.

[17] A.F. Moghaddam and A. Van Den Bossche, "An Active Cell Equalization Technique for Lithium Ion Batteries Based on Inductor Balancing," 9th International Conference on Mechanical and Aerospace Engineering (ICMAE), Budapest, pp. 274-278, 2018.

[18] Ali Farzan Moghaddam and Alex Van Den Bossche, "An efficient equalizing method for lithium-ion batteries based on coupled inductor balancing," Electronics, vol. 8, pp. 136, 2019.

[19] Y. Shang, et al., "A Modularization Method for Battery Equalizers Using Multi winding Transformers," in IEEE Transactions on Vehicular Technology, vol. 66, no. 10, pp. 8710-8722, Oct. 2017.

[20] A. F. Moghaddam and A. Van den Bossche, "Multi-Winding Equalization Technique for Lithium Ion Batteries for Electrical Vehicles," 2018 7th International Conference on Renewable Energy Research and Applications (ICRERA), Paris, pp. 139-143, 2018.

[21] Y. Ma, Ahsanuzzaman and A. Prodić, "A hardware efficient lithium-ion cell balancing technique utilizing lowvolume hybrid DC-DC converter," IECON 2017 - 43rd Annual Conference of the IEEE Industrial Electronics Society, Beijing, pp. 566-570, 2017.

[22] Yewen Wei, et al., "Switch Matrix Algorithm for Series Lithium Battery Pack Equilibrium Based on Derived Acceleration Information Gauss-Seidel," Mathematical Problems in Engineering, Article ID 8075453,

Int J Pow Elec \& Dri Syst, Vol. 11, No. 2, June 2020 : $571-579$ 
9 pages, 2019.

[23] Z. Amjadi and S. S. Williamson, "Power-Electronics-Based Solutions for Plug-in Hybrid Electric Vehicle Energy Storage and Management Systems," in IEEE Transactions on Industrial Electronics, vol. 57, no. 2, pp. 608-616, Feb 2010.

[24] S. Sreelakshmi and K. Deepa, "Fuzzy based bidirectional converter," International Conference on Circuits, Power and Computing Technologies [ICCPCT-2015], Nagercoil, 2015, pp. 1-6, 2015.

[25] Y. Ma, et al., "Equalization of Lithium-Ion Battery Pack Based on Fuzzy Logic Control in Electric Vehicle," in IEEE Transactions on Industrial Electronics, vol. 65, no. 8, pp. 6762-6771, Aug. 2018.

[26] Y. Shang, et al., "An Automatic Equalizer Based on Forward-Fly-back Converter for Series-Connected Battery Strings," IEEE Transactions on Industrial Electronics, vol. 64, no. 7, pp. 5380-5391, July 2017.

[27] Kaliyaperumal.Deepa, et al., "Active clamp zero voltage switching multiple output fly-back converter with voltage doubler," International Review on Modeling and Simulations, vol. 6, pp. 351-359, 2013.

[28] E. Chatzinikolaou and D. J. Rogers, "Electrochemical cell balancing using a full-bridge multilevel converter and pseudo-open circuit voltage measurements," 8th IET International Conference on Power Electronics, Machines and Drives (PEMD 2016), Glasgow, pp. 1-6, 2016.

[29] Q. Ouyang, et al., "SOC Estimation-Based Quasi-Sliding Mode Control for Cell Balancing in Lithium-Ion Battery Packs," in IEEE Transactions on Industrial Electronics, vol. 65, no. 4, pp. 3427-3436, April 2018.

[30] Ali Farzan Moghaddam and Alex Van Den Bossche, "A 'Cuk Converter Cell Balancing Technique by Using Coupled Inductors for Lithium-Based Batteries," Energies, vol. 12, pp. 2881, 2019.

[31] Shubiao, et al., "A Novel Layered Bidirectional Equalizer Based on a Buck-Boost Converter for Series-Connected Battery Strings," Energies, vol. 10, 2017.

[32] Y. Shang, et al., "A Cell-to-Cell Battery Equalizer With Zero-Current Switching and Zero-Voltage Gap Based on Quasi-Resonant LC Converter and Boost Converter," IEEE Transactions on Power Electronics, vol. 30, no. 7, pp. 3731-3747, July 2015.

[33] T. Gotwald, et al., "Equalization of EV and HEV batteries with a ramp converter", IEEE Transactions on Aerospace and Electronic Systems, vol. 33, no. 1, pp. 307-312, Jan. 1997.

[34] Thiruvonasundari.D, K. Deepa, "Electric Vehicle Battery Modelling Methods Based on State of Charge-Review," Journal of Green Engineering (2020 in press).

[35] S. Narayanaswamy, et al., "Modular Active Charge Balancing for Scalable Battery Packs," IEEE Transactions on Very Large-Scale Integration (VLSI) Systems, vol. 25, no. 3, pp. 974-987, March 2017. 